UDC 691

\title{
On the properties of nano-modified cement stones
}

\author{
Authors: \\ Vakhitova Roza II., \\ Associate Professor, PhD in Engineering, Almetyevsk State Oil Institute; Almetyevsk, Russia, \\ e-mail: roza-w@mail.ru;
}

Saracheva Diana A.,

$\mathrm{PhD}$ in Engineering, Senior Lecturer, Almetyevsk State Oil Institute; Almetyevsk, Russia, e-mail: sarachevadiana85@mail.ru;

Mazankina Daria V.,

Senior Lecturer, Almetyevsk State Oil Institute; Almetyevsk, Russia, e-mail: daria-mazankina@yandex.ru

Kiyamov Ilgam K.,

Professor, Doctor of Economics, Kazan (Volga Region) Federal University, Engineering Institute; Kazan, Russia, e-mail: kiyamov.ilgam@mail.ru;

\section{Sabitov Linar S.,}

Associate Professor, PhD in Engineering, Kazan (Volga Region) Federal University, Engineering Institute; Kazan, Russia, e-mail: sabitov-kgasu@mail.ru

\footnotetext{
Abstract: The use of nanotechnology in the construction industry improves its efficiency. The application of nano-modified materials makes it possible to reduce capital costs. Currently the introduction of nanomaterials is of great importance for the construction industry. Carbonaceous structures can be used as nano-modifiers. Carbon nanotubular material TUBALL produced by OCSiAl.ru LLC has been chosen.

To perform research samples of single-layer and multi-walled carbon nanotubes were used as a part of cement heavy concrete. The optimal dosage of carbon nanotubes in the composition of cement concrete has been experimentally determined. The studies revealed that addition of TUBALL carbon nanotubes to the cement composition contributed to the formation of a mesh structure that resists the formation of shrinkable nanoscale cracks in the cement mortar, promotes the appearance of calcium hydrosilicates, increases the concentration of calcium ions at the start of the hydration period.

The influence of modified nanoadditives in the composition of the complex additive on the mechanical properties of the cement composition has been considered. The complex of mechanical properties of cement nanoreinforced stone in the process of cementing the annular space of producing wells by X-ray and thermal methods of analysis has been studied. That confirmed the results of experiments performed with electronic and optical microscopy.

The microstructural elements of the cement specimen were investigated with high-resolution auto-emission scanning electron microscope Merlin by CARL ZEISS.

It was found that the addition of complex nanomodified additive TUBALL accelerates the curing of the cement composite at early stage of hardening, decreases value of shrinkable nano-cracks, that in turn positively characterizes the quality of contacts at the boundaries of cement-casing, rock-cement.
}

Keywords: heavy concrete, hyperplasticizer, water repellent, nano-modified cement stone, nanomaterials, TUBALL, single-layer and multi-layered carbon nanotubes, hardening, curing, dispersion.

For citation: Vakhitova R.I., Saracheva D.A., Mazankina D.V., Kiyamov I.K., Sabitov L.S. On the properties of nano-modified cement stones. Nanotehnologii v stroitel'stve = Nanotechnologies in Construction. 2019, Vol. 11, no. 5, pp. 565-576. DOI: 10.15828/20758545-2019-11-5-565-576. 
$<$ rel="license" href="http://creativecommons.org/licenses/by/4.0/"><img alt="Creative Commons License" style="border-width:0" src="https://i.creativecommons. org/l/by/4.0/88x31.png" / ></a $><$ br / > span xmlns:dct="http://purl.org/dc/terms/" href="http://purl.org/dc/dcmitype/Text" property="dct:title" rel="dct:type" $>$ On the properties of nano-modified cement stones $</$ span $>$ by $<$ a xmlns:cc="http://creativecommons.org/ns\#" href="Nanotehnologii v stroitel'stve = Nanotechnologies in Construction. 2019, Vol. 11, no. 5, pp. 565-576. DOI: 10.15828/2075-8545-2019-11-5-565-576" property="cc:attributionName" rel="cc:attributionURL">Vakhitova R.I., Saracheva D.A., Mazankina D.V., Kiyamov I.K., Sabitov L.S.</a > is licensed under a <a rel="license" href="http://creativecommons.org/licenses/by/4.0/" $>$ Creative Commons Attribution 4.0 International License $</ \mathrm{a}>$. $<$ br $/>$ Based on a work at $<$ a xmlns:dct="http://purl.org/dc/terms/" href="http://nanobuild.ru/en_EN/nanobuild-5-2019/" rel="dct:source" > http://nanobuild.ru/en_EN/nanobuild-5-2019/</a $>$. $<$ br $/>$ Permissions beyond the scope of this license may be available at $<$ a xmlns:cc="http://creativecommons.org/ns\#" href="sarachevadiana85@mail.ru" rel="cc:morePermissions" $>$ sarachevadiana85@mail.ru</a $>$.

\title{
О свойствах наномодифицированных цементных камней
}

\author{
Авторы: \\ Вахитова Роза Ильгизовна, \\ доцент, кандидат технических наук, Альметьевский государственный нефтяной институт; Альметьевск, Россия, \\ e-mail: roza-w@mail.ru;

\section{Сарачева Диана Азатовна,} \\ кандидат технических наук, старший преподаватель, Альметьевский государственный нефтяной институт; \\ Альметьевск, Россия, е-mail: sarachevadiana85@mail.ru; \\ Мазанкина Дарья Владимировна, \\ старший преподаватель, Альметьевский государственный нефтяной институт; Альметьевск, Россия, \\ e-mail: daria-mazankina@yandex.ru;
}

\section{Киямов Ильгам Киямович,}

доктор экономических наук, профессор, Казанский (Приволжский) федеральный университет, Инженерный институт; Казань, Россия, e-mail: kiyamov.ilgam@mail.ru;

\section{Сабитов Линар Салихзанович,}

кандидат технических наук, доцент, Казанский (Приволжский) федеральный университет, Инженерный институт;

Казань, Россия, e-mail: sabitov-kgasu@mail.ru

Резюме: Использование нанотехнологий в строительной отрасли позволяет повысить её эффективность. Использование наномодифицированных материалов даёт возможность снизить капитальные затраты. В настоящее время для строительной индустрии актуально внедрение наноматериалов. В качестве наномодификаторов можно применять углеродосодержащие структуры. Выбрали углеродный нанотубулярный материал TUBALL производства OOO «OCSiAl.ru».

Для проведения исследований использовались образцы однослойных и многослойных углеродных нанотрубок в составе цементного тяжелого бетона. Экспериментально определялась оптимальная дозировка углеродных нанотрубок в составе цементного бетона. При проведении исследований выявлено, что добавление углеродных нанотрубок TUBALL в цементную композицию способствовало образованию сетчатой структуры, которая оказывает сопротивление образованию усадочных наноразмерных трещин в цементном растворе, способствует появлению новообразований в виде гидросиликатов кальция, повышает на старте периода гидратации концентрацию ионов кальция.

Рассмотрели влияние модифицированных исследуемых нанодобавок в составе комплексной добавки на механические свойства цементной композиции. Изучили комплекс механических свойств цементного наноармированного камня в процессе цементирования затрубного пространства добывающих скважин рентгеновским и термическим методами анализа, это подтвердило эксперименты с применением электронной и оптической микроскопии.

Исследовали микроструктурные элементы цементного образца с применением высокоразрешающего автоэмиссионного сканирующего электронного микроскопа Merlin компании CARL ZEISS. 
Установлено, что добавление комплексной наномодифицированной добавки TUBALL способствует ускорению набора прочности цементного композита на ранней стадии твердения, уменьшению значения усадочных нанотрещин, что, в свою очередь, положительно характеризует качество контактов на границах цемент-обсадная колонна, порода-цемент.

Ключевые слова: тяжелый бетон, гиперпластификатор, гидрофобизатор, наномодифицированный цементный камень, наноматериалы, TUBALL, однослойные и многослойные углеродные нанотрубки, твердение, набор прочности, диспергация.

Для цитирования: Вахитова Р.И., Сарачева Д.А., Мазанкина Д.В., Киямов И.К., Сабитов Л.С. О свойствах наномодифицированных цементных камней // Нанотехнологии в строительстве. - 2019. - Том 11, № 5. - С. 565-576. - DOI: 10.15828/20758545-2019-11-5-565-576.

Машиночитаемая информация о СС-лицензиях (HTML-код) в метаданных статьи

$<$ a rel="license" href="http://creativecommons.org/licenses/by/4.0/"><img alt="Creative Commons License" style="border-width:0" src="https://i.creativecommons. org/l/by/4.0/88x31.png"/></a ><br/><span xmlns:dct="http://purl.org/dc/terms/" href="http://purl.org/dc/dcmitype/Text" property="dct:title" rel="dct:type" >On the properties of nano-modified cement stones $</$ span $>$ by $<$ a xmlns:cc="http://creativecommons.org/ns\#" href="Nanotehnologii $v$ stroitel'stve $=$ Nanotechnologies in Construction. 2019, Vol. 11, no. 5, pp. 565-576. DOI: 10.15828/2075-8545-2019-11-5-565-576" property="cc:attributionName" rel="cc:attributionURL">Vakhitova R.I., Saracheva D.A., Mazankina D.V., Kiyamov I.K., Sabitov L.S.</a $>$ is licensed under a $<$ a rel="license" href="http://creativecommons.org/licenses/by/4.0/" $>$ Creative Commons Attribution 4.0 International License $</ \mathrm{a}>$. $<\mathrm{br} />$ Based on a work at $<$ a xmlns:dct="http://purl.org/dc/terms/" href="http://nanobuild.ru/en_EN/nanobuild-5-2019/" rel="dct:source" $>$ http://nanobuild.ru/en EN/nanobuild-5-2019/</a $>.<\mathrm{br} />$ Permissions beyond the scope of this license may be available at $<$ a xmlns:cc="http://creativecommons.org/ns\#" href="sarachevadiana85@mail.ru" rel="cc:morePermissions" $>$ sarachevadiana85@mail.ru $</ a>$.

Статья поступила в редакцию: 09.09.2019.

Статья поступила в редакцию после рецензирования: 30.09.2019.

Статья принята к публикации: 02.10.2019.

\section{INTRODUCTION}

$\mathrm{M}_{\mathrm{s}}^{\mathrm{s}}$ odern research in the field of nanotechnology is supported by the government of the Russian Federation and is included in the list of priority areas for the development of science and technology. The Republic of Tatarstan gives proper heed to the creation of new products modified by nanotubes [1].

Scientific practical interest particularly focused on improvement of the operational properties of concrete based on its modification with the addition of chemical additives, such as carbon nanotubes to produce the necessary import-substituting and export-oriented articles [2-4].

In accordance with the order of the Cabinet of Ministers of the Republic of Tatarstan of July 16, 2015. No. 1561, activity plan was developed to support the creation of products based on single-walled carbon nanotubes (TUBALL) at the enterprises of the Republic of Tatarstan for 2015-2018, namely, methods for introducing nanotubes into various building materials, determination ща the strength characteristics of building materials depending on the technological input modes, contents and properties of TUBALL nanotubes.

At the present stage of nanotechnology development, the study of the properties of concrete modified by nano- tubes is also of interest from a scientific and practical point of view [5-7].

There are certain requirements for cement stones. If cement stone is used in wells, it is necessary to change the indicators of water separation and filtration, setting time, thickening time, and to improve sedimentation stability in nanoreinforcing process [8-10].

There are different types of nanoadditives [11-13]. It is most rational to use elongated nanoparticles to improve the physicochemical properties of cement stone [14, 15]. Among them, carbon nanotubes can be distinguished. They have several advantages: high strength, inertness to alkalis and acids, they also well reinforce cement mortar and represent crystallization centers, turn cement composites into high-strength material [16-18].

To modify the structure of cement composites with nanosized particles, two directions are used [19-21]:

- targeted growth of nanoscale particles to modify the structure in a hardening binder system;

- preliminary synthesis of nanosized particles, their subsequent introduction into the desired composition.

Currently, the second method is mostly used, however, due to the high surface activity of nanosized tubes in the synthesis process, they are combined in the form of powdery granules into conglomerates, and this by 
the volume of the composite solution makes their uniform distribution difficult. As a result, this technology contributes to the production of a material having a high heterogeneity in density, strength, and other properties [22-24].

\section{MAIN PART}

Studies of the effect of nanotubes on the properties of cement mortar, which is a model of heavy concrete, were presented $[25,26]$. The cement-sand mortar consisted of cement and sand in a ratio of 1:3. Then it was shut with water from the water supply, and a suspension of carbon nanotubes in a solution consisting of water, a hydrophobizing agent and a mixture of hyperplasticizer was previously mixed in it. Preliminary, all components of the solution were subjected to ultrasonic dispersion to ensure a homogeneous mass of this suspension [27]. The ultrasonic dispersion process lasted 3.5 minutes, the volume of the suspension was $100 \mathrm{ml}$, and the power was 100 watts. As a hyperplasticizer, an additive with a high early strength set of Remicrete SP 60 based on polycarboxyl ethers was used. As a water-repellent additive, Tiprom-S was used, having an organosilicon composition of $55 \%$ concentrate based on potassium alkyl siliconate.

TUBALL carbon nanotubular material manufactured by OCSiAl.ru LLC was used as a complex additive with a hydrophobizing agent and hyperplasticizer. Singlewalled nanotubes had a specific geometric surface from $90 \mathrm{mg}$ to $130 \mathrm{mg}$, multilayer nanotubes had a specific geometric surface from $180 \mathrm{mg}$ to $200 \mathrm{mg}$ [5]. The specific surface area was determined with the Bruner-EmmettTeller (BET) multipoint method.

The optimal dosage of carbon nanotubes in cement concrete was experimentally determined. For singlewalled carbon nanotubes, it amounted to $0.005 \%$ by weight of the cement composition, and for multilayer carbon nanotubes, it was $0.0005 \%$ by weight of the cement composition.
In the process of conducting experimental studies, it was clarified and revealed that the addition of TUBALL carbon nanotubes to the cement composition contributed to the formation of a network structure. This structure, in turn, resists the formation of nanoscale shrinkage cracks in the cement mortar, contributes to the appearance of neoplasms in the form of calcium hydrosilicates, and increases the concentration of calcium ions at the start of the hydration period.

The effect of the studied modified nanosupplements in the composition of the complex additive on the mechanical properties of the cement composition is considered. The complex of mechanical properties of cement nanoreinforced stone in the process of cementing the annular space of production wells by X-ray and thermal analysis methods was also studied, that confirmed electron and optical microscopy experiments [28-30].

In accordance with GOST 310.4-81 «Cements. Methods for determining the ultimate strength in bending and compression» experimental work was carried out using cement based on Portland cement clinker CEM Ш / A 32.5H manufactured by «Ulyanovsk Cement Plant». As a filler of a shallow medium, sand was used from the Kamskoe Ustye deposit, having a particle size modulus of 2.7. The dosage of nano-additives was taken as a percentage of the mass of cement (table 1).

To investigate microstructure of cement a high-resolution Merlin field-emission scanning electron microscope from CARL ZEISS was used, which is applied to measure linear microrelief sizes of solid-state structures. Test chips of the cement composite were sprayed in a 80/20 ratio with an Au / Pd alloy in a Quorum 150 T ES vacuum unit. To conduct fundamental research on the properties of nanomaterials, the analytical equipment of the Center of Nanotechnologies of the Republic of Tatarstan LLC was used - a Smartlab automatic X-ray diffractometer (RIGAKU) and a STA 6000 synchronous thermal analyzer (PERKIN ELMER), which makes it possible to measure thermophysical characteristics (temperature and heat of physicochemical reactions and phase transitions).

\section{Table 1}

\section{Dosage of nano-additives}

\begin{tabular}{|c|c|c|c|c|}
\hline \multirow{2}{*}{$\begin{array}{c}\text { Number of composi- } \\
\text { tion }\end{array}$} & \multicolumn{4}{|c|}{ Supplement dosage, \% } \\
\cline { 2 - 5 } & Hyperplasticizer & Water repellent & $\begin{array}{c}\text { Single Layer Carbon } \\
\text { Nanotubes }\end{array}$ & $\begin{array}{c}\text { Multilayer Carbon } \\
\text { Nanotubes }\end{array}$ \\
\hline 1 & 0 & 0 & 0 & 0 \\
\hline 2 & 1 & 0,1 & 0 & 0 \\
\hline 3 & 1 & 0 & 0 & 0 \\
\hline 4 & 1 & 0,1 & 0,005 & 0 \\
\hline 5 & 1 & 0,1 & 0 & 0,0005 \\
\hline
\end{tabular}


a)

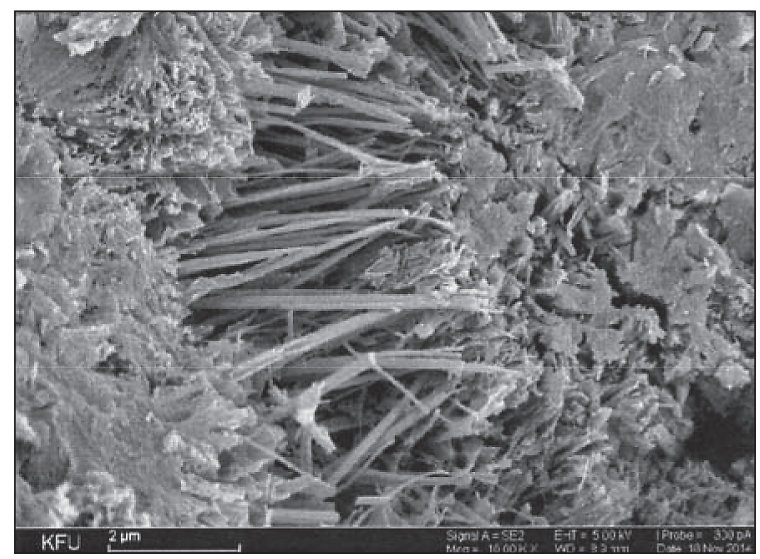

c)

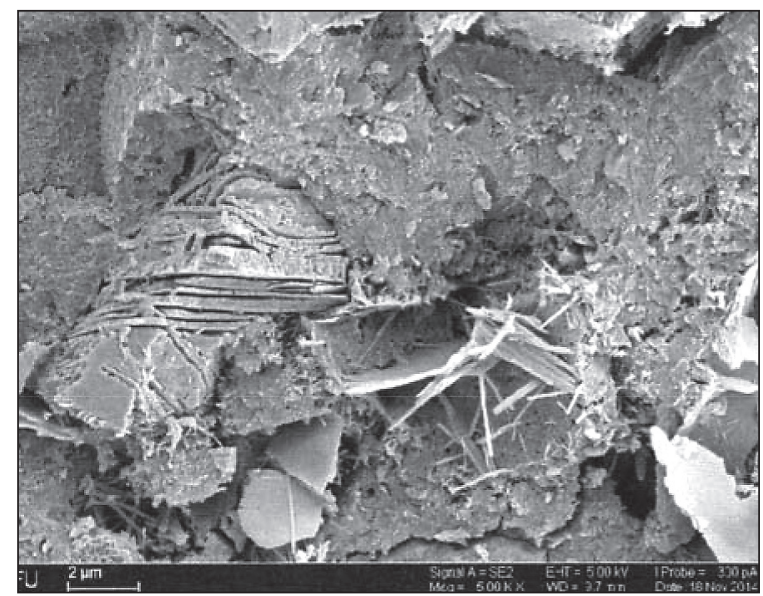

Using this equipment, the compositions of the hydration products of the modified Tuball nanotubes and the initial cement stones were studied. Electronic images of samples of cement stones are shown in the figure. b)

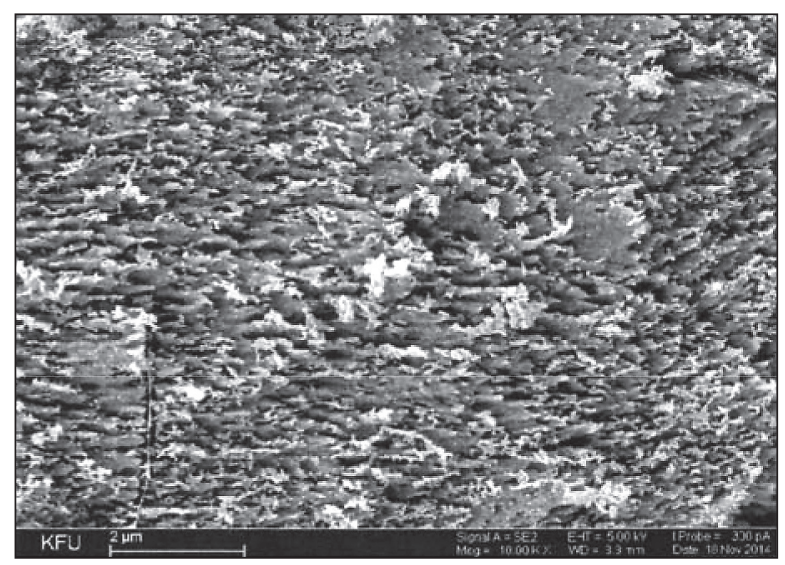

Fig. Electronic images of samples of cement stones:

a) control sample (magnification 10,000);

b) a sample with single-walled nanotubes

(an increase of 10,000);

c) a sample with multilayer nanotubes

(magnification 5000)

An analysis of the figure shows that the addition of carbon single-walled nanotubes promotes the formation of a dense fine-crystalline homogeneous structure in comparison with the control composition of cement

Table 2

Mechanical properties of modified cement stone

\begin{tabular}{|c|c|c|c|c|c|}
\hline \multirow{3}{*}{$\begin{array}{c}\text { Number } \\
\text { of composition }\end{array}$} & \multirow{3}{*}{$\begin{array}{c}\text { The water-cement } \\
\text { ratio of the control } \\
\text { sample, } \%\end{array}$} & \multicolumn{4}{|c|}{ Strength, MPa } \\
\hline & & \multicolumn{2}{|c|}{ under compression } & \multicolumn{2}{|c|}{ when bending } \\
\hline & & 7 days & 28 days & 7 days & 28 days \\
\hline 1 & $\frac{42}{100}$ & $\frac{39,96}{100}$ & $\frac{39,96}{100}$ & $\frac{4,19}{100}$ & $\frac{4,96}{100}$ \\
\hline 2 & $\frac{32}{76}$ & $\frac{44,90}{122}$ & $\frac{44,90}{122}$ & $\frac{5,04}{130}$ & $\frac{5,76}{126}$ \\
\hline 3 & $\frac{32}{76}$ & $\frac{50,35}{129}$ & $\frac{50,35}{129}$ & $\frac{5,67}{135}$ & $\frac{6,44}{130}$ \\
\hline 4 & $\frac{32}{76}$ & $\frac{51,95}{146}$ & $\frac{51,95}{146}$ & $\frac{5,91}{141}$ & $\frac{6,74}{136}$ \\
\hline 5 & $\frac{32}{76}$ & $\frac{47,95}{119}$ & $\frac{47,95}{119}$ & $\frac{4,94}{118}$ & $\frac{5,90}{119}$ \\
\hline
\end{tabular}

Note. Numerical values are above the line, relative values in $\%$ of the control are below the line. 
stone. When carbon multilayer nanotubes are added to the cement composite, the microstructure of the cement sample is characterized by a more loose inhomogeneous structure. The mechanical properties of the modified cement stone are given in table 2.

From the analysis of table 2 it follows that introduction of additives Remicrete SP60 (composition No. 3) to the cement composition increases the strength characteristic when bending the cement after 7 days of normal hardening by $35 \%$, after 28 days by $30 \%$, and under compression, an increase in strength is $42 \%$ and $22 \%$, respectively, with respect to the control composition.

The modified cement mortar, in which single-walled carbon nanotubes are dispersed in a solution of hyperplasticizer and water repellent (composition No. 4), showed a maximum increase in strength. The strength characteristics during bending for 7 and 28 days of hardening increase by $41 \%$ and $36 \%$, respectively, with compression, the increase in strength is $55 \%$ and $46 \%$, respectively, with respect to the control composition.

The addition of carbon multilayer nanotubes to cement stones compared to single-layer ones is characterized by less effect on the strength of the cement composite, both in bending and in compression (composition No. 5).

\section{CONCLUSION}

It was found that the addition of a complex nanomodified additive helps to accelerate the curing of the cement composite at an early stage of hardening, to reduce the value of shrinkage nanocracks, that in turn positively characterizes the quality of the contacts at the cementcasing, rock-cement boundaries.

\section{ВВЕДЕНИЕ}

$\mathrm{C}$ овременные исследования в области нанотехнологий поддерживаются Правительством Российской Федерации и внесены в список приоритетных направлений развития науки и техники. В Республике Татарстан уделяется должное внимание созданию новой продукции, модифицированной нанотрубками [1].

Особый научный практический интерес представляет улучшение эксплуатационных свойств бетона на основе его модификации с добавлением химических добавок, а именно углеродных нанотрубок для производства необходимых импортозамещающих и экспортоориентированных продуктов [2-4].

В соответствии с распоряжением КМ РТ от 16.07.2015г. № 1561 разработан план мероприятий по поддержке создания продуктов на основе одностенных углеродных нанотрубок (TUBALL) на предприятиях Республики Татарстан на 2015-2018 годы, а именно методики введения нанотрубок в различные строительные материалы, определение прочностных характеристик строительных материалов в зависимости от технологических режимов ввода, содержания и свойств нанотрубок TUBALL.

На современном этапе развития нанотехнологий изучение свойств бетона, модифицированного нанотрубками, представляет собой интерес и с научной, и практической точек зрения [5-7].

К цементным камням предъявляются определенные требования. В случае если цементный камень используется в скважинах, то при наноармировании тре- буется изменить показатели водоотделения и фильтрации, сроков схватывания, времени загустевания, улучшения седиментационной устойчивости [8-10].

Существуют разные виды нанодобавок [11-13]. Наиболее рационально применять вытянутые наночастицы для улучшения физико-Химических свойств цементного камня [14, 15]. Среди них можно выделить углеродные нанотрубки. Они обладают рядом достоинств: высокая прочность, инертность к щелочам и кислотам, хорошо армируют цементный раствор, представляют собой центры кристаллизации, превращают цементные композиты в высокопрочный материал [16-18].

Для модифицирования структуры цементных композитов наноразмерными частицами применяются два направления [19-21]:

- целенаправленное выращивание наноразмерных частиц для модифицирования структуры в твердеющей вяжущей системе;

- предварительный синтез наноразмерных частиц, последующее их введение в требуемую композицию.

В настоящее время наибольшее распространение получил второй метод, однако в силу высокой поверхностной активности наноразмерных трубок в процессе синтеза они объединяются в виде порошкообразных гранул в конгломераты, а это по объему композиционного раствора затрудняет их равномерное распределение. В результате эта технология способствует получению материала, имеющего высокую неоднородность по плотности, прочности и другим свойствам [22-24]. 


\section{1. Экспериментальные исследования наномодифи- цированного цементного камня}

Приводились исследования влияния нанотрубок на свойства цементного раствора, представляющего собой модель тяжелого бетона $[25,26]$. Цементнопесчаный раствор состоял из цемента и песка в соотношении 1:3. Далее его затворяли водой из водопровода, а в ней заранее размешивалась суспензия углеродных нанотрубок в растворе, состоящем из воды, гидрофобизатора и смеси гиперпластификатора. Предварительно все компоненты раствора подвергались воздействию ультразвуковой диспергации для обеспечения однородной массы данной суспензии [27]. Процесс ультразвукового диспергирования длился 3,5 минуты, объем суспензии составил 100 мл, а мощность - 100 Вт. В качестве гиперпластификатора применялась добавка с высоким ранним набором прочности Remicrete SP 60 на основе поликарбоксилатэфиров. В качестве гидрофобизирующей добавки использовался Типром-С, имеющий кремнийорганический состав из 55\%-ого концентрата на основе алкилсиликоната калия.

В качестве комплексной добавки с гидрофобизатором и гиперпластификатором применялись углеродный нанотубулярный материал TUBALL производства OOO «OCSiAl.ru». Однослойные нанотрубки имели удельную геометрическую поверхность от 90 до 130 мг, многослойные нанотрубки - удельную геометрическую поверхность от 180 до 200 мг [5]. Удельная поверхность определялась по многоточечному методу Брюнера-Эммета-Теллера (БЭТ).

Экспериментально определили оптимальную дозировку углеродных нанотрубок в составе цементного бетона. Для однослойных углеродных нанотрубок она составила $0,005 \%$ от массы цементной композиции, а для многослойных - 0,0005\% от массы цементной композиции.
В процессе проведения экспериментальных исследований уточнили и выявили, что добавление углеродных нанотрубок TUBALL в цементную композицию способствовало образованию сетчатой структуры. Эта структура в свою очередь оказывает сопротивление образованию наноразмерных усадочных трещин в цементном растворе, способствует появлению новообразований в виде гидросиликатов кальция, повышает на старте периода гидратации концентрацию ионов кальция.

Рассмотрено влияние исследуемых модифицированных нанодобавок в составе комплексной добавки на механические свойства цементной композиции. Также изучен комплекс механических свойств цементного наноармированного камня в процессе цементирования затрубного пространства добывающих скважин рентгеновским и термическим методами анализа, что явилось подтверждением экспериментов электронной и оптической микроскопии [28-30].

В соответствии с ГОСТ 310.4-81 «Цементы. Методы определения предела прочности при изгибе и сжатии» выполнялись экспериментальные работы с использованием цемента на основе портландцементного клинкера ЦЕМ Ш/А $32.5 \mathrm{H}$ производства «Ульяновский цементный завод». В качестве заполнителя мелкой среды применялся песок из месторождения Камское Устье, имеющий модуль крупности 2,7. Дозировка нанодобавок принималась в процентных соотношениях от массы цементного раствора (табл. 1).

Исследовали микроструктуры цемента. Для этого применяли высокоразрешающий автоэмиссионный сканирующий электронный микроскоп Merlin компании CARL ZEISS, который используется для выполнения измерений линейных микрорельефных размеров твердотельных структур. Пробные сколы цементного композита напыляли в соотношении 80/20 сплавом $\mathrm{Au} / \mathrm{Pd}$ на вакуумной установке

\section{Таблииа 1}

Дозировка нанодобавок

\begin{tabular}{|c|c|c|c|c|}
\hline \multirow{2}{*}{$\begin{array}{c}\text { Номер } \\
\text { состава }\end{array}$} & Гиперпластификатор & Гидрофобизатор & $\begin{array}{c}\text { Дозировка добавок, \% } \\
\text { Однослойные } \\
\text { углеродные } \\
\text { нанотрубки }\end{array}$ & $\begin{array}{c}\text { Многослойные } \\
\text { углеродные } \\
\text { нанотрубки }\end{array}$ \\
\hline 1 & 0 & 0 & 0 & 0 \\
\hline 2 & 1 & 0,1 & 0 & 0 \\
\hline 3 & 1 & 0 & 0 & 0 \\
\hline 4 & 1 & 0,1 & 0,005 & 0 \\
\hline 5 & 1 & 0,1 & 0 & 0,0005 \\
\hline
\end{tabular}


a)

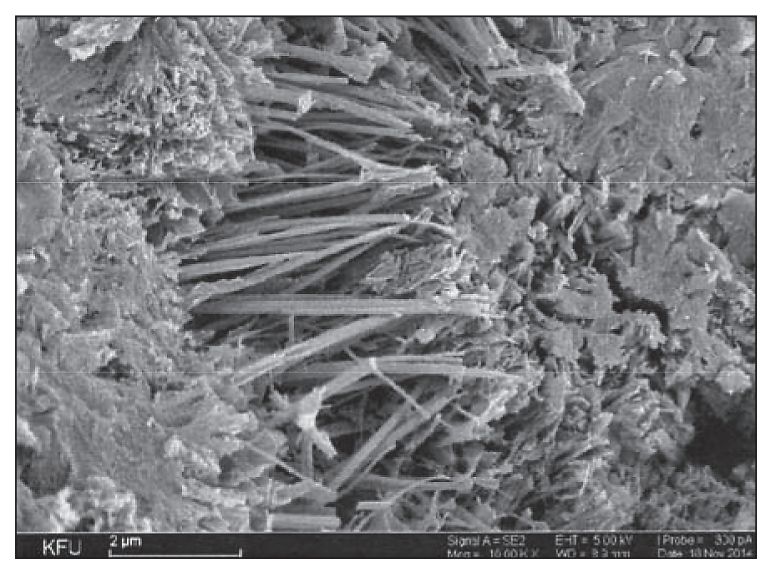

в)

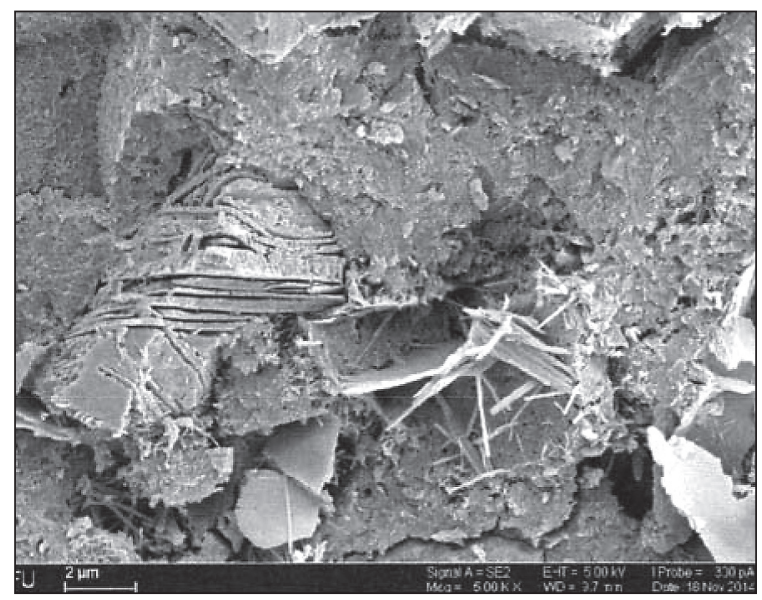

б)

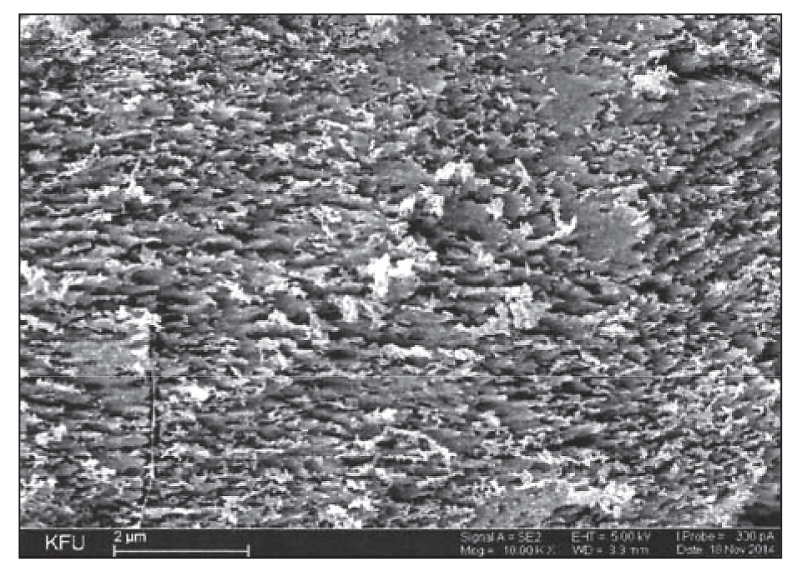

Рис. Электронные снимки образцов цементных камней:

a) контрольный образец (увеличение 10000);

б) образец с однослойными нанотрубками

(увеличение 10000);

в) образец с многослойными нанотрубками

(увеличение 5000)

Quorum 150 T ES. Для проведения фундаментальных исследований свойств наноматериалов применялось аналитическое оборудование ООО «Центр нанотехнологий Республики Татарстан» - автоматический рентгеновский дифрактометр Smartlab (RIGAKU) и синхронный термоанализатор STA 6000 (PERKIN ELMER), который дает возможность измерять термофизические характеристики (температуру и теплоту физико-химических реакций и фазовых переходов). С помощью этого оборудования изучили составы продуктов гидратации модифицированного нанотрубками Tuball и исходного цементных камней. Электронные снимки образцов цементных камней приведены на рис.

Анализ рис. показывает, что добавление углеродных однослойных нанотрубок способствует образованию плотной мелкокристаллической однородной структуры по сравнению с контрольным составом цементного камня. При добавлении углеродных многослойных нанотрубок в цементный композит микроструктура цементного образца отличается более рыхлой неоднородной структурой. Механические свойства модифицированного цементного камня приведены в табл. 2.

Из анализа табл. 2 следует, что при добавлении в цементный состав добавки с высоким ранним набором прочности Remicrete SP60 (состав № 3) прочностная характеристика при изгибе цементного раствора через 7 суток нормального твердения увеличивается на $35 \%$, через 28 суток - на $30 \%$, а при сжатии повышение прочности составляет соответственно по отношению к контрольному составу $42 \%$ и $22 \%$.

Модифицированный цементный раствор, в котором однослойные углеродные нанотрубки диспергированы в растворе гиперпластификатора и гидрофобизатора (состав № 4), показал максимальный прирост прочности. Прочностная характеристика при изгибе на 7 и 28 сутки твердения увеличивается на $41 \%$ и $36 \%$, соответственно, при сжатии повышение прочности составляет соответственно по отношению к контрольному составу на $55 \%$ и $46 \%$.

Добавление углеродных многослойных нанотрубок в цементные камни по сравнению с однослойными характеризуется меньшим влиянием на прочность цементного композита, как при изгибе, так и при сжатии (состав № 5). 


\section{Таблица 2}

Механические свойства модифицированного цементного камня

\begin{tabular}{|c|c|c|c|c|c|}
\hline \multirow{3}{*}{$\begin{array}{l}\text { Номер } \\
\text { состава }\end{array}$} & \multirow{3}{*}{$\begin{array}{c}\text { Водоцементное } \\
\text { отношение } \\
\text { контрольного } \\
\text { образца, \% }\end{array}$} & \multicolumn{4}{|c|}{ Прочность, МПа } \\
\hline & & \multicolumn{2}{|c|}{ при сжатии } & \multicolumn{2}{|c|}{ при изгибе } \\
\hline & & 7 суток & 28 суток & 7 суток & 28 суток \\
\hline 1 & $\frac{42}{100}$ & $\frac{39,96}{100}$ & $\frac{39,96}{100}$ & $\frac{4,19}{100}$ & $\frac{4,96}{100}$ \\
\hline 2 & $\frac{32}{76}$ & $\frac{44,90}{122}$ & $\frac{44,90}{122}$ & $\frac{5,04}{130}$ & $\frac{5,76}{126}$ \\
\hline 3 & $\frac{32}{76}$ & $\frac{50,35}{129}$ & $\frac{50,35}{129}$ & $\frac{5,67}{135}$ & $\frac{6,44}{130}$ \\
\hline 4 & $\frac{32}{76}$ & $\frac{51,95}{146}$ & $\frac{51,95}{146}$ & $\frac{5,91}{141}$ & $\frac{6,74}{136}$ \\
\hline 5 & $\frac{32}{76}$ & $\frac{47,95}{119}$ & $\frac{47,95}{119}$ & $\frac{4,94}{118}$ & $\frac{5,90}{119}$ \\
\hline
\end{tabular}

Примечание. Над чертой - числовые значения, под чертой - относительные значения в \% от контрольных.

\section{ЗАКЛЮЧЕНИЕ}

Установлено, что добавление комплексной наномодифицированной добавки способствует ускорению набора прочности цементного композита на ранней стадии твердения, уменьшению значения усадочных нанотрещин, что в свою очередь положительно характеризует качество контактов на границах цементобсадная колонна, порода-цемент.

\section{REFERENCES}

1. Khavkin A.Ya. Nanoyavleniya i nanotekhnologii v dobyche nefti i gaza [Nanophenomena and nanotechnologies in oil and gas production]. Moscow - Izhevsk, NITS «Regulyarnaya i khaoticheskaya dinamika», Institut komp'yuternykh issledovaniy [SIC «Regular and chaotic dynamics», Institute for Computer Studies], 2010, 692 p. (In Russian).

2. Korolev E. V. Osnovnye printsipy prakticheskoy nanotekhnologii V stroitelnom materialovedenii [The basic principles of practical nanotechnology in building materials]. Nanotekhnologii v stroitelstve: nauchnyy internet-zhurnal [Nanotechnology in Construction: A Scientific Internet-Journal], 2009, no. 1, pp. 66-79. (In Russian).

3. Maeva I.S., Yakovlev G.I., Izryadnova O.V., Khasanov O.L. Strukturirovanie angidridovykh matrits uglerodnymi nanosistemami [Structuring anhydride matrices with carbon nanosystems]. Materialy XV Akademicheskikh chteniy RAASN [Materials of the XV Academic Readings of the RAACS], 2010, pp. 294-298. (In Russian).

4. Roko M.K., Williams R.S., Alivatos P. Nanotekhnologii v blizhaysheye desyatiletiye. Prognoznyye napravleniya issledovaniy [Nanotechnology in the coming decade. Forecast areas of research]. Moscow, Mir [World], 2002, 292 p. (in Russian).

5. Foster L.E. Nanotekhnologii. Nauka, innovatsii i vozmozhnosti [Nanotechnology. Science, Innovation and Opportunity]. Moscow, Tekhnosfera [Technosphere], 2008, 352 p. (In Russian).

6. Dixon J.B. Diversity of natural nanoparticles in soils and causative factors implied. Mineralogia - Special Papers: $4^{\text {th }}$ MidEuropean Clay Conference MECC, Zakopane, Poland, 2008, pp. 54.

7. Brat S., Singh P. Use of Nanorobots in Oil Industry. Maharashtra Institute of Technology. SPE Mumbai Section, 2006.

8. Falikman V.R. Nanomaterialy i nanotekhnologii v sovremennyh betonah [Nanomaterials and nanotechnologies in modern concretes]. Promyshlennoye i grazhdanskoye stroitel'stvo [Industrial and civil engineering], 2013, no. 1, pp. 31-34. (In Russian).

9. Ponomarev A.N. Nanobeton - ponyatiye i problemy. Sinergizm nanostrukturirovannykh tsementnykh vyazhushchikh i anizotropnykh dobavok [Nanoconcrete - the concept and problems. Synergism of nanostructuring cement binders and anisotropic additives]. Stroitel'nyye materialy [Construction materials], 2007, no. 6. (In Russian).

10. Voytovich V.A., Khryapchenkova I.N. Nanobeton v stroitelstve [Nanoconcrete in construction]. Stroitel'nyye materialy [Construction materials], 2016, no. 9, pp. 73-75. (In Russian).

11. Patrikeev L.N. Nanotekhnologii v energetike [Nanotechnologies in power engineering]. Nanoindustriya [Nanoindustry], 2008, no. 2, pp. 14-15. (In Russian). 
12. Detlef B., Klaus S. Chemomechanical processing - the innovative way of integrating nanoparticles into industrial products. PETROTECH, New Delhi, India. 2009. p. 286.

13. Zaporotskova I.V. Uglerodnyye i neuglerodnyye nanomaterialy i kompozitnyye struktury na ikh osnove: stroyeniye i elektronnyye svoystva [Carbon and non-carbon nanomaterials and composite structures based on them: structure and electronic properties]. Volgograd. Izd-vo Volgogradskogo gos. un-va (Publishing house of the Volgograd State the university), 2009 , 488 p. (In Russian).

14. Shah K.A., Najar F.A., Andrabi S.M.A., Islam S.S. Synthesis of carbon nanotubes for device applications. Asian Journal of Chemistry, 2017, vol. 29, no. 4, pp. 879-881.

15. Danoglidis P.A., Falara M.G., Maglogianni M., Konsta-Gdoutos M.S. Scalable processing of cementitious composites reinforced with carbon nanotubes (CNTs) and carbon nanofibers (CNFs). Nanotehnologii $\mathrm{v}$ stroitel'stve $=$ Nanotechnologies in Construction. 2019, Vol. 11, no. 1, pp. 20-27. DOI: 10.15828/2075-8545-2019-11-1-20-27.

16. Yakovlev G.I., Pervushin G.N., Bur'yanov A.F., Kodolov V.I., Krutikov V.A., Fisher F.-B., Kerene Ya. Modifikatsiya porizovannykh tsementnykh matrits uglerodnymi nanotrubkami [Modification of porous cement matrices with carbon nanotubes]. Stroitel'nye materialy [Construction materials], 2009, no. 3, pp. 99-102. (In Russian).

17. Rayfti, S., Chegini, E. K. Highly selective and green oxidation of sulfides with urea hydrogen peroxide in the presence of MN (III) porphyrin supported onto carbon nanotubes. Macroheterocycles, 2016, vol. 9, no. 2, pp. 151-155. DOI: 10.6060/mhc151101r.

18. Khussein S.M.R.H., Hanfar A. Uglerodnyye nanotrubki: problemy i perspektivy ikh ispolzovaniya [Carbon nanotubes: problems and prospects for their use]. Uspekhi sovremennoy nauki [Advances in modern science], 2017, vol. 4, no. 4, pp. $166-169$. (In Russian).

19. Mazurenko V.V., Rudenko A.N., Mazurenko V.G. Nanochastitsy, nanomaterialy, nanotekhnologii. Uchebnoye posobiye [Nanoparticles, nanomaterials, nanotechnologies. Tutoria]. Yekaterinburg. Federal'noye agentstvo po obrazovaniyu, Ural'skiy gos. tekhnicheskiy un-t - UPI im. pervogo Prezidenta Rossii B. N. Yel'tsina [Federal Agency for Education, Ural State Technical University - UPI them. first President of Russia B. N. Yeltsin], 2009, 83 p. (In Russian).

20. Mishchenko S.V., Tkachev A.G. Uglerodnyye nanomaterialy. Proizvodstvo, svoystva, primeneniye [Carbon nanomaterials. Production, properties, application]. Moscow, Mashinostroyeniye [Mechanical Engineering], 2008. (In Russian).

21. Shevchenko V.Ya. Institut khimii silikatov RAN. Issledovaniya v oblasti nanomira i nanotekhnologiy [Institute of Silicate Chemistry RAS. Research in the field of nanoworld and nanotechnology]. Rossiyskiye nanotekhnologii [Russian nanotechnology], 2008, vol. 3, no. 11-12, pp. 36-45. (In Russian).

22. Kehl A.V. Fullereny i uglerodnyye nanotrubki [Fullerenes and carbon nanotubes]. Innovatsionnaya nauka [Innovation science], 2016, № 11-3, pp. 23-25. (In Russian).

23. Salamatov V.I., Vasilyeva K.S. Uglerodnyye nanotrubki - osnova perspektivnykh nanomaterialov [Carbon nanotubes the basis of promising nanomaterials]. Zhiznennyy tsikl konstruktsionnykh materialov (ot polucheniya do utilizatsii): materialy dokladov V Vserossiyskoy nauchno-tekhnicheskoy konferentsii s mezhdunarodnym uchastiyem [Life cycle of structural materials (from production to disposal): materials of reports of the Vth All-Russian Scientific and Technical Conference with international participation], 2015, pp. 247-254. (In Russian).

24. Lebeda Yu.V. Uglerodnyye nanotrubki: ikh svoystva i metody modifikatsii [Carbon nanotubes: their properties and methods of modification]. Nedelya nauki SPbGPU: materialy XLII nauchno-prakticheskoy konferentsii c mezhdunarodnym uchastiyem [SPbGPU Science Week: Proceedings of the XLII Scientific Practical Conference with international participation], 2014 , pp. 30-32. (In Russian).

25. Tang Q., Huang J., Tian G. Dispersion of carbon nanotubes and research progress on mechanical properties of carbon nanotubes cement-based composites. Gongneng Cailiao, 2017. vol. 48, no. 6, pp. 42-49.

26. László I., Gyimesi B., Koltai J., Kürti J. Molecular dynamics simulation of carbon structures inside small diameter carbon nanotubes. Physica Status Solidi (B): Basic Solid State Physics, 2017, vol. 254, no. 11, pp. 170-206.

27. Gabidullin M.G., Khuzin A.F., Rakhimov R.Z., Tkachev A.G. Ultrazvukovaya obrabotka - effektivnyy metod dispergirovaniya uglerodnykh nanotrubok v ob"eme stroitelnogo kompozita [Ultrasonic processing is an effective method for dispersing carbon nanotubes in the bulk of a composite composite]. Stroitelnye materialy [Construction materials], 2013, no. 2, pp. 57-59. (In Russian).

28. Kiyamov I.K., Mingazov R.Kh., Vakhitova R.I., Kiyamova L.I., Sibgatullin A.A., Saracheva D.A., Mazankina D.V. K voprosu ob issledovanii tamponazhnykh rastvorov na osnove uglerodnykh nanotrubok i ikh vliyaniya na fazovyy sostav tsementnogo kamnya pri stroitel'stve skvazhin [On the study of cement slurries based on carbon nanotubes and their influence on the phase composition of cement stone in the construction of wells]. Materialy nauchnoy sessii uchenykh Al'met'yevskogo gosudarstvennogo neftyanogo institute [Materials of the scientific session of scientists of the Almetyevsk State Oil Institute], 2016, no. 2, pp. 48-50. (In Russian).

29. Semenov V.A., Rusakov S.V., Buzmakova M.M. Issledovaniye anizotropnoy provodimosti epoksidnogo polimera, modifitsirovannogo uglerodnymi nanotrubkami [Study of the anisotropic conductivity of epoxy polymer modified with carbon nanotubes]. Sbornik trudov 8-y Vserossiyskoy nauchnoy konferentsii s mezhdunarodnym uchastiyem im. I.F. Obraztsova i YU.G. Yanovskogo [Collection of works of the 8th All-Russian Scientific Conference with international participation. I.F. Obraztsova and Yu.G. Yanovsky], 2019, pp. 92-95. (In Russian).

30. Guz A.N., Rushchitskii Y.Y. Nanomaterials: on the mechanics of nanomaterials. International applied mechanics, 2003, vol. 39, no. 11, pp. 1271-1293. DOI: 10.1023/B:INAM.0000015598.53063.26. 


\section{СПИСОК ЛИТЕРАТУРЫ}

1. Хавкин А.Я. Наноявления и нанотехнологии в добыче нефти и газа. - Москва-Ижевск: НИЦ «Регулярная и хаотическая динамика», Институт компьютерных исследований, 2010. - 692 с.

2. Королев Е.В. Основные принципы практической нанотехнологии в строительном материаловедении // Нанотехнологии в строительстве. - 2009. - № 1. - С. 66-79.

3. Маева И.С., Яковлев Г.И., Изряднова О.В., Хасанов О.Л. Структурирование ангидридовых матриц углеродными наносистемами // Материалы XV Академических чтений РАACH. - 2010. - С. 294-298.

4. Роко М.К., Уильямс Р.С., Аливатос П. Нанотехнология в ближайшем десятилетии. Прогноз направления исследований. - М: Мир, 2002. - 292с.

5. Фостер Л.Э. Нанотехнологии. Наука, инновации и возможности - М: Техносфера, 2008. - 352c.

6. Dixon J.B. Diversity of natural nanoparticles in soils and causative factors implied // Mineralogia - Special Papers: $4^{\text {th }}$ MidEuropean Clay Conference MECC, Zakopane, Poland, 2008, pp. 54.

7. Brat S., Singh P. Use of Nanorobots in Oil Industry. Maharashtra Institute of Technology, SPE Mumbai Section, 2006.

8. Фаликман В.Р. Наноматериалы и нанотехнологии в современных бетонах // Промышленное и гражданское строительство. - 2013. - № 1. - С. 31-34.

9. Пономарев А.Н. Нанобетон - концепция и проблемы. Синергизм наноструктурирования цементных вяжущих и анизотропных добавок // Строительные материалы. - 2007. - № 6.

10. Войтович В.А., Хряпченкова И.Н. Нанобетон в строительстве // Строительные материалы. - 2016. - № 9. C. $73-75$.

11. Патрикеев Л.Н. Нанотехнологии в энергетике // Наноиндустрия. - 2008. - № 2. - С. 14-15.

12. Detlef B., Klaus S. Chemomechanical processing - the innovative way of integrating nanoparticles into industrial products // PETROTECH, New Delhi, India, 2009, pp. 286.

13. Запороцкова И.В. Углеродные и неуглеродные наноматериалы и композитные структуры на их основе: строение и электронные свойства. - Волгоград: Изд-во Волгоградского гос. ун-ва, 2009. - 488c.

14. Shah K.A., Najar F.A., Andrabi S.M.A., Islam S.S. Synthesis of carbon nanotubes for device applications // Asian Journal of Chemistry, 2017, vol. 29, no. 4, pp. 879-881.

15. Danoglidis Panagiotis A., Falara Maria G., Maglogianni Myrsini, Konsta-Gdoutos Maria S. Scalable processing of cementitious composites reinforced with carbon nanotubes (CNTS) and carbon nanofibers (CNFS) // Нанотехнологии в строительстве: научный интернет-журнал. - 2019. - Т. 11. - № 1. - С. 20-27. DOI: 10.15828/2075-8545-2019-11-1-20-27.

16. Яковлев Г.И., Первушин Г.Н., Бурьянов А.Ф., Кодолов В.И., Крутиков В.А., Фишер Ф. - Б., Керене Я. Модификация поризованных цементных матриц углеродными нанотрубками // Строительные материалы. - 2009. - № 2. C. $99-102$.

17. Rayfti, S., Chegini, E. K. Highly selective and green oxidation of sulfides with urea hydrogen peroxide in the presence of MN (III) porphyrin supported onto carbon nanotubes // Макрогетероциклы. - 2016. - Т. 9. - №2. - C. 151-155. DOI: $10.6060 / \mathrm{mhc} 151101 \mathrm{r}$.

18. Хуссейн С. М. Р. Х., Ханфар А. Углеродные нанотрубки: проблемы и перспективы их использования // Успехи современной науки. - 2017. - Т. 4 - № 4. - С. 166-169.

19. Мазуренко В.В., Руденко А.Н., Мазуренко В.Г. Наночастицы, наноматериалы, нанотехнологии. Учебное пособие. - Екатеринбург: Федеральное агентство по образованию, Уральский гос. технический ун-т - УПИ им. первого Президента России Б. Н. Ельцина, 2009. - 83 с.

20. Мищенко С.В., Ткачев А.Г. Углеродные наноматериалы. Производство, свойства, применение. - М: Машиностроение, 2008.

21. Шевченко В.Я. Институт химии силикатов РАН. Исследования в области наномира и нанотехнологий // Российские нанотехнологии. - 2008. - Т. 3, № 11-12. - С. 36-45.

22. Кель А.В. Фуллерены и углеродные нанотрубки // Инновационная наука. - 2016. - № 11-3. - С. $23-25$.

23. Саламатов В.И., Васильева К.С. Углеродные нанотрубки - основа перспективного наноматериала // Жизненный цикл конструкционных материалов (от получения до утилизации): материалы докладов V Всероссийской научно-технической конференции с международным участием. - Иркутск, 2015. - С. 247-254.

24. Лебеда Ю.В. Углеродные нанотрубки: их свойства и методы модификации // Неделя науки СПбГПУ: материалы XLII научно-практической конференции с международным участием. - Санкт-Петербург, 2014. - C. 30 -32.

25. Tang Q., Huang J., Tian G. Dispersion of carbon nanotubes and research progress on mechanical properties of carbon nanotubes cement-based composites // Gongneng Cailiao, 2017. vol. 48, no. 6, pp. 42-49.

26. László I., Gyimesi B., Koltai J., Kürti J. Molecular dynamics simulation of carbon structures inside small diameter carbon nanotubes // Physica Status Solidi (B): Basic Solid State Physics, 2017, vol. 254, no. 11, pp. 170-206.

27. Габидуллин М.Г., Хузин А.Ф., Рахимов Р.З., Ткачев А.Г. Ультразвуковая обработка - эффективный метод диспергирования углеродных нанотрубок в объеме строительного композита // Строительные материалы. - 2013. - № 2. C. $57-59$.

28. Киямов И.К., Мингазов Р.Х., Вахитова Р.И., Киямова Л.И., Сибгатуллин А.А., Сарачева Д.А., Мазанкина Д.В. К вопросу об исследовании тампонажных растворов на основе углеродных нанотрубок и их влияния на фазовый состав 
STUDY OF PROPERTIES OF NANOMATERIALS • ИССЛЕДОВАНИЕ СВОЙСТВ НАНОМАТЕРИАЛОВ

цементного камня при строительстве скважин // Материалы научной сессии ученых Альметьевского государственного нефтяного института. - 2016. - № 2. - С. 48-50.

29. Семенов В. А., Русаков С. В., Бузмакова М. М. Исследование анизотропной проводимости эпоксидного полимера, модифицированного углеродными нанотрубками // Сборник трудов 8-й Всероссийской научной конференции с международным участием им. И.Ф. Образцова и Ю.Г. Яновского. - 2019. - С. 92-95.

30. Guz A.N., Rushchitskii Y.Y. Nanomaterials: on the mechanics of nanomaterials // International applied mechanics, 2003, vol. 39, no. 11, pp. 1271-1293. DOI: 10.1023/B:INAM.0000015598.53063.26.

\section{INFORMATION ABOUT THE AUTHORS}

Vakhitova Roza II., PhD in Engineering, Associate Professor, Department «Electrical and Thermal Power Engineering, Almetyevsk State Oil Institute»; Lenina st., 2a, Almetyevsk, Republic of Tatarstan, the Russian Federation, 423450, roza-w@mail.ru;

Saracheva Diana A., PhD in Engineering, Senior Lecturer, Department «Electrical and Thermal Power Engineering», Almetyevsk State Oil Institute; Lenina st., 2a, Almetyevsk, Republic of Tatarstan, the Russian Federation, 423450, sarachevadiana85@mail.ru;

Mazankina Daria V., Senior Lecturer, Department «Electrical and Heat Power Engineering», Almetyevsk State Oil Institute; Lenina st., 2a, Almetyevsk, Republic of Tatarstan, the Russian Federation, 423450, daria-mazankina@yandex.ru;

Kiyamov Ilgam K., Engineering Institute, Doctor of Economics, Professor, Department of Biomedical Engineering and Innovation Management, Kazan (Volga Region) Federal University; Kremlin st., 18, Kazan, Republic of Tatarstan, the Russian Federation, 420008, kiyamov.ilgam@mail.ru;

Sabitov Linar S. Engineering Institute, Candidate of Technical Sciences, Associate Professor, Department of Biomedical Engineering and Innovation Management, Kazan (Volga Region) Federal University; Kremlin st., 18, Kazan, Republic of Tatarstan, the Russian Federation, 420008, sabitov-kgasu@mail.ru

\section{ИНФОРМАЦИЯ ОБ АВТОРАХ}

Вахитова Роза Ильгизовна, кандидат технических наук, доцент кафедры «Электро- и теплоэнергетика», Альметьевский государственный нефтяной институт; ул. Ленина, 2а, г. Альметьевск, Республика Татарстан, Россия, 423450, roza-w@mail.ru

Сарачева Диана Азатовна, кандидат технических наук, старший преподаватель кафедры «Электрои теплоэнергетика», Альметьевский государственный нефтяной институт; ул. Ленина, 2а, г. Альметьевск, Республика Татарстан, Россия, 423450, e-mail: sarachevadiana85@mail.ru;

Мазанкина Дарья Владимировна, старший преподаватель кафедры «Электро- и теплоэнергетика», Альметьевский государственный нефтяной институт; ул. Ленина, 2а, г. Альметьевск, Республика Татарстан, Россия, 423450, daria-mazankina@yandex.ru

Киямов Ильгам Киямович, доктор экономических наук, профессор кафедры «Биомедицинская инженерия и управление инновациями», Инженерный институт, Казанский (Приволжский) федеральный университет; ул. Кремлевская, д. 18, г. Казань, Республика Татарстан, Россия, 420008, kiyamov.ilgam@mail.ru;

Сабитов Линар Салихзанович, кандидат технических наук, доцент, доцент кафедры «Биомедицинская инженерия и управление инновациями», Инженерный институт, Казанский (Приволжский) федеральный университет; ул. Кремлевская, д. 18, г. Казань, Республика Татарстан, Россия, 420008, sabitov-kgasu@mail.ru 